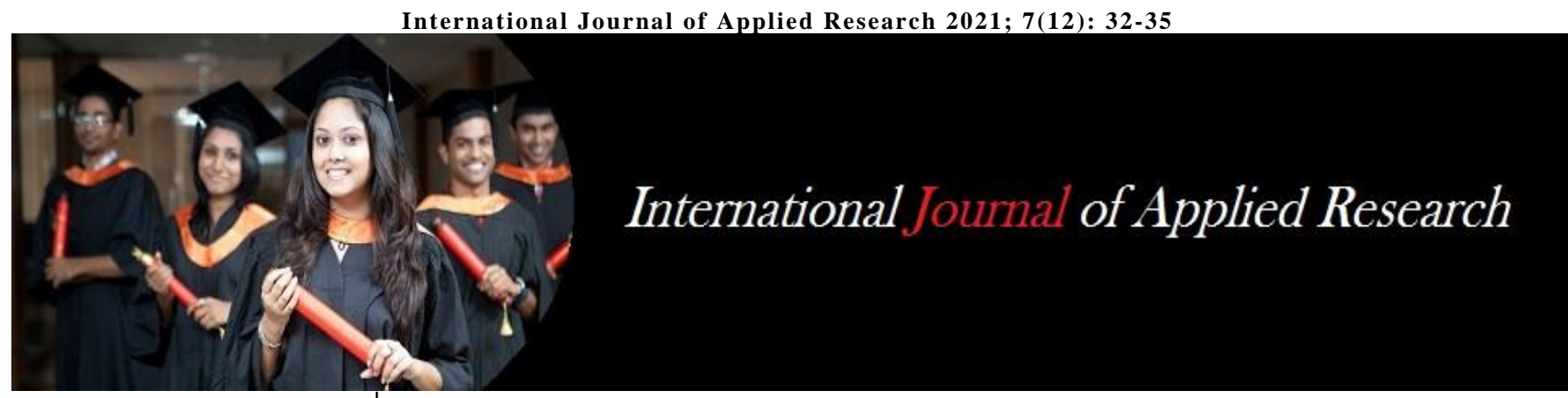

ISSN Print: 2394-7500

ISSN Online: 2394-5869

Impact Factor: 8.4

IJAR 2021; 7(12): 32-35

www.allresearchjournal.com

Received: 25-10-2021

Accepted: 27-11-2021

Rajesh A

Research Scholar,

Post Graduate and Research,

Department of Commerce,

Mar Ivanios College

(Autonomous), Trivandrum,

Kerala, India

Dr. Arun Lawrence

Assistant Professor,

Post Graduate and Research,

Department of Commerce

Mar Ivanios College

(Autonomous) Trivandrum,

Kerala, India
Corresponding Author:

Rajesh A

Research Scholar,

Post Graduate and Research,

Department of Commerce,

Mar Ivanios College

(Autonomous), Trivandrum,

Kerala, India

\section{Trends and pattern of household savings and investment in India}

\author{
Rajesh A and Dr. Arun Lawrence
}

DOI: https://doi.org/10.22271/allresearch.2021.v7.i12a.9179

\section{Abstract}

The household sector is the largest contributor to the GDP of the Indian economy so it is very much important to know how much does this sector contributes to the growth of this economy. It is being estimated that the household sector holds more than 50 percent capital formation of the country and due to many factors, such as employment, technological growth, etc., these fluctuates. Traditionally the household savings were limited to physical assets but due to a changing economic situation, there has been a slight shift from physical to financial assets taking different platforms of savings and investment. The Indian economy has experienced a slowdown in domestic savings in the year 2019 which was 2.3 percent than in 2018 and 1.3 percent than in 2017. The Indian domestic savings has consistently faced a slowdown from 2011 to date. Due to the COVID-19, the GDP of India in the second quarter of 2020 was contracted to 23.9 percent, which was estimated as the lowest rate of GDP. This paper explores the concepts of household savings, investment, and its dependent variables by using secondary data.

Keywords: investment, savings, financial \& non- financial assets, GDP, economic growth

\section{Introduction}

In the Indian context, an individual in old age has to depend on their savings or joint family support, because of which it is said that there is no generalized social security system in India. Therefore, in the context of increased life expectancy and the decline of the joint family system, there is always a need for a suitable plan for investment. The savings culture of India is such that they save for their children's education, the marriage of their children, overall family health care needs, and contingencies if any. For accomplishing all these there should be a long-term perspective about savings and the knowledge about the sort of returns that they get from their investment.

The activity or practice of investing money for future profit or the commitment of money or other resources to something that will hopefully provide value in the future is defined as an investment. It can be in the form of stocks, bonds, or a sum of money allocated to capital expenditures that increase the production capacity of goods and services available to the market. In simple terms, investment leads to productivity, and productivity, in turn, leads to economic growth. (Hundie, 2014) ${ }^{[3]}$ On a deeper level, investment can take the form of purchasing stock, bonds, and or other financial assets, while on a larger scale, investments back into capital also known as real asset investment or physical investment have a direct impact on economic growth.

"If a country wants to grow sustainably, it must increase investment, but investment requires funding," said Pranjul Bhandari, chief Indian economist at HSBC. When an economy's savings rise and mobilisation is efficient, it shows up in investments as funds are made available to individuals who invest through the banking system. The savings and investing habits of a country are also important. The government sector, the public corporate sector, which only comprises registered enterprises under the company act 2013, and the private sector are the three largest sources of savings for the economy. Individuals, trusts, partnerships, and sole proprietorships, among others, make up households. Households contribute more to GDP than the government and the Public Corporate Sector (PCS) together. (Jayasinghe et al., 2019) ${ }^{[4]}$. Savings in the household sector account for the majority of total domestic savings. It is divided into two categories: financial assets and physical assets. 
Savings in the form of currency, bank deposits, non-bank deposits, life insurance funds, provident and pension funds, claim on government, shares, and debentures including Mutual fund investments and net trade debt are all included in the household sector's gross financial savings.

\section{Household Savings}

Household savings is the difference between income and expenditure and as previously stated domestic savings is a combination of government, private sector, and household savings, with Indian households accounting for roughly 60 percent of the country's savings. This directly reflects the impact of the household sector in channelling and facilitating the investment process in a country. Savings in the home represents the household sector's savings from disposable income. In a mature economy, household savings are reflected in their investments in various financial instruments issued by intermediaries such as banks and financial institutions as well as the government net of their obligations. Apart from financial savings, a component of physical savings is also estimated in India which includes household expenditure on housing construction.

In recent years, Indian households have shifted their investments and savings from physical assets such as real estate and gold to financial assets which are more useful in terms of economic growth.

\section{Household Financial Savings}

Currency, bank deposits, debt securities, mutual funds, pension funds, insurance, and investments in modest savings programs are all examples of household financial savings. Gross household financial savings refers to the sum of these savings. Net household financial savings is what remains after financial liabilities such as loans from banks, nonbanking financial firms (NBFCs), and home financing companies are removed from gross savings. In 2019-2020, net household financial savings increased from 7.2 percent of GDP in 2018-19 to 7.7 percent. Liabilities declined from 3.9 percent of GDP in $2018-19$ to 2.9 percent in $2019-20$ causing this.

\section{Household Savings in Financial Assets}

The excess of aggregate capital formation measured by the product flow technique is referred to as financial assets or the availability of items like machinery, equipment, and construction material that enter into capital formation. From the foregoing, it should be obvious that household saving is generated as a residual category in both homes financial and household physical asset savings or household capital formation. (Saikia, 2015) Commercial bank deposits made up to 52.6 percent of total deposits. Currency is made up to 13.4 percent of the total, 23.2 percent of the portfolio was made up of life insurance holdings and mutual funds holdings was made up to 7 percent of total holdings.

In 2020, the data depicts the proportion of household financial assets. The majority of financial savings are made through bank deposits (52.6 percent), followed by life insurance funds (23.2 percent). We have currency in the third level with a proportion of 13.4 percent, mutual fund investment in the fourth level with a rate of 7.0 percent, and cooperative bank rate of 3.8 percent as the last source of household savings. We cannot make a comparison with the previous years because the year 20201 is still in progress; however, we will be able to do so after this year when the whole data is available for analysis.

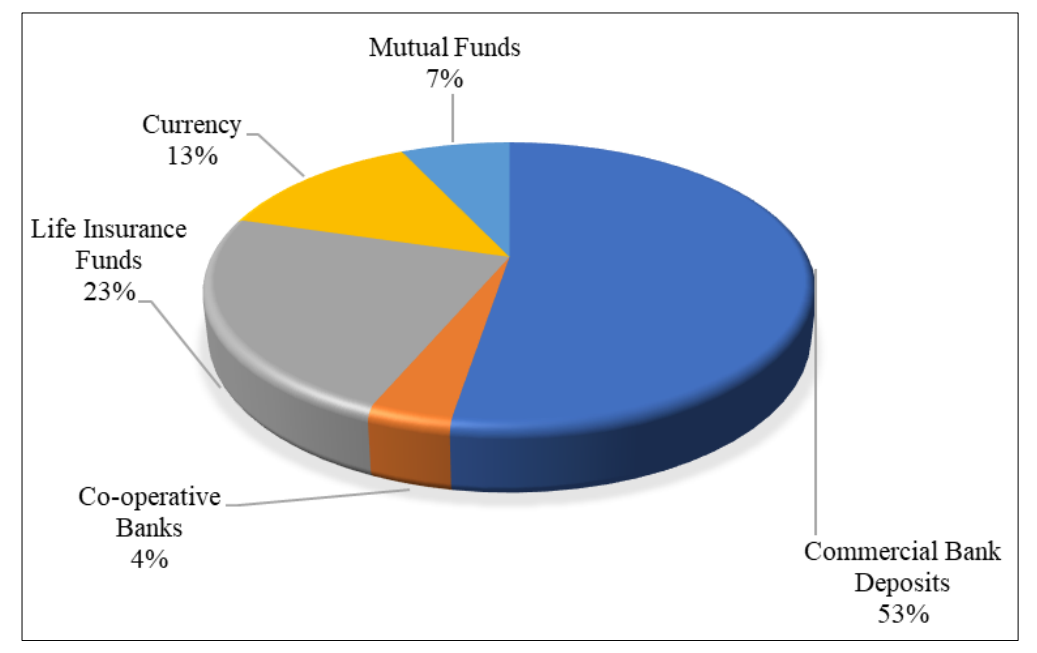

Fig 1: Composition of Household Financial Assets- Outstanding Position (As at end of March 2020)

\section{Household Investment}

In the twenty-first century, investing is simply sending money to someone (a bank, a person, or a corporation, etc.) in exchange for a guaranteed return. Many factors must be considered before investing, depending on the platform for investment; an analysis of the economy, industry, and company, as well as the trend of that particular platform over time, should be studied and analysed before making an investment decision. Additionally, while investing one should understand liquidity, the risk appetite of the investor, amount of investment, and period of investment. An investment with a high risk may yield a high profit while a low-risk investment yields a low profit. (Patnaik \& Pandey, 2019) [5] The period for investment is critical as it determines how much the return must be to suit the investor's needs. Investments can be short or long-term. Households invest in the following primary forms of investments such as deposits in the bank, company deposits, and mutual fund schemes; stocks (shares), small-scale saving plans, pension plans based on government bonds. Indians are risk-averse and do not invest heavily in equitylinked plans. Traditional investment choices such as provident funds and bank accounts are preferred by them. 
Table 1: Gross Financial Assets of Households (As a percent of GDP)

\begin{tabular}{|c|c|c|c|c|c|c|c|c|c|c|c|c|c|c|c|}
\hline \multirow{2}{*}{ Items } & \multicolumn{5}{|c|}{$2017-18$} & \multicolumn{5}{|c|}{ 2018-19 } & \multicolumn{5}{|c|}{ 2019-20 } \\
\hline & Q1 & Q2 & Q3 & Q4 & Annual & Q1 & Q2 & Q3 & \begin{tabular}{|l|l|} 
Q4 \\
\end{tabular} & \begin{tabular}{|l|} 
Annual \\
\end{tabular} & Q1 & Q2 & Q3 & Q4 & Annual \\
\hline Gross Financial Assets & 9.6 & 13.8 & 7.9 & 16.5 & 12.0 & 7.9 & 10.4 & 7.3 & 18.8 & 11.1 & 6.7 & 10.3 & 10.7 & 14.5 & 10.6 \\
\hline 1. Total Deposits (a) $+(\mathrm{b})$ & -1.6 & 5.9 & -1.2 & 8.6 & 2.9 & -1.2 & 6.5 & 0.5 & 10.2 & 4.0 & -0.7 & 5.9 & 2.1 & 7.1 & 3.6 \\
\hline (a) Bank Deposits & -1.8 & 5.9 & -1.4 & 8.6 & 2.8 & -1.4 & 6.3 & 0.3 & 10.2 & 3.8 & -1.0 & 5.6 & 2.0 & 7.2 & 3.4 \\
\hline (i) Commercial Bank Dep & -1.5 & 5.7 & -1.5 & 8.6 & 2.8 & -1.4 & 6.2 & 0.2 & 9.9 & 3.7 & -1.1 & 5.5 & 1.2 & 7.1 & 3.2 \\
\hline (ii) Cooperative Banks & -0.3 & 0.2 & 0.1 & 0.1 & 0.0 & -0.1 & 0.1 & 0.0 & \begin{tabular}{|l|l|}
0.3 \\
\end{tabular} & 0.1 & 0.0 & 0.1 & 0.8 & 0.1 & 0.3 \\
\hline (b) Non- Bank Deposits & 0.2 & 0.1 & 0.2 & 0.0 & 0.1 & 0.2 & 0.2 & 0.2 & 0.1 & 0.2 & 0.4 & 0.3 & 0.1 & 0.0 & 0.2 \\
\hline 2. Life Insurance Funds & 1.9 & 2.3 & 3.1 & 0.9 & 2.0 & 1.5 & 2.1 & 1.1 & 3.1 & 1.9 & 2.0 & 0.8 & 2.1 & 1.8 & 1.7 \\
\hline 3. Provident and Pension Funds (including PPF) & 2.3 & 2.2 & 2.1 & 2.1 & 2.2 & 2.2 & 2.1 & 2.1 & 2.1 & 2.1 & 2.2 & 2.2 & 2.1 & 2.1 & 2.2 \\
\hline 4. Currency & 4.8 & 1.0 & 2.6 & 3.0 & 2.8 & 2.5 & -0.7 & 2.1 & 1.9 & 1.5 & 1.3 & -0.5 & 1.7 & 3.0 & 1.4 \\
\hline 5. Investments & 1.3 & 1.5 & 0.4 & 1.1 & 1.1 & 1.7 & -0.8 & 0.5 & 0.3 & 0.4 & 0.6 & 0.5 & 1.3 & -0.8 & 0.4 \\
\hline Mutual Funds & 1.2 & 1.3 & 0.0 & \begin{tabular}{|l|}
0.8 \\
\end{tabular} & 0.8 & 1.5 & -1.0 & 0.4 & \begin{tabular}{|l|l|}
0.2 \\
\end{tabular} & 0.3 & 0.2 & 0.4 & 1.3 & -0.9 & 0.2 \\
\hline 6. Small Savings (excluding PPF) & 1.0 & 0.9 & 0.9 & 0.8 & 0.9 & 1.1 & 1.1 & 1.1 & 1.0 & 1.1 & 1.4 & 1.4 & 1.3 & 1.3 & 1.3 \\
\hline
\end{tabular}

Source: Quarterly Reports of RBI

As a result of the foregoing data, it can be concluded that savings are made in both bank deposits and non-bank deposits with 3.4 percent of total deposits made in bank deposits and 0.2 percent in non-bank deposits in 2019-2020. However, bank deposits have decreased by 0.4 percent from 2018 to 2019, while non-bank deposits have remained unchanged. Saving in life insurance funds has decreased gradually from 2017 to 2019-2020 indicating a decreased willingness to invest in life insurance funds. Provident funds and pension funds have a fixed rate of return. In the last four years currency has depreciated. Investment has been consistent in 2018 and 2019 and mutual funds, in particular, have depreciated gradually. In general, financial assets savings and investment by the household sector have decreased from 12 percent in $2017-18$ to 11.1 percent in 2018-19 to 10.6 percent in 2019-20. (FE Bureau, 2020) ${ }^{[2]}$

\section{Savings and Investment Trends in Indian Economy}

Savings are a good indicator of how much a country's citizens are going to invest because the more the savings the higher the investment. Households account for more than half of the country's overall savings. According to the Harrod-Domar model of economic growth, the degree of savings is a critical component in determining growth rates. Savings in the private sector, in the public sector, and the household sector, make up Gross Domestic Savings. In India, the savings rate or the proportion of gross domestic savings in GDP has been declining during the last decade. Given the tough global environment, managing a country's savings is critical in a fast-growing economy like India. To finance investments and maintain growth, saving sources such as household, business and government are required. (Patnaik \& Pandey, 2019) ${ }^{[5]}$ According to the Household Finance Committee, physical assets account for the majority of household savings with real estate accounting for 77 percent of assets, durable items such as agriculture machinery accounting for 7 percent, gold accounting for 11 percent, and financial assets accounting for 5 percent. Durable items and gold account for a big portion of young household's wealth but land and houses account for the majority of their wealth as they approach retirement. According to data provided by Central Statistics Office (CSO), India's Gross Domestic Savings Rate in 2019 is 30.1 percent falling 2.3 percent from the previous year.

The low savings rate has a direct influence on investment. The Gross Domestic Savings Rate is calculated on a yearly basis with the year ending in March. According to recent figures, India's GDP shrank by 23.9 percent year over year in June 2020. Because India's nominal GDP was 502.1 USD in June 2020. The gross domestic savings for the year 2020 is estimated as 31.40 percent as seen in the graph above. When a country's savings rate falls it may be forced to borrow more from foreign markets. India's external position will be damaged in international terms as a result of the increase in national debt. (CIEC, 2019) ${ }^{[1]}$

According to Bhandari, in order to increase investments at a time when savings are dropping the current account balance must decrease or the current account deficit must widen, necessitating additional foreign inflows. Economists believe that a reduction in the savings rate can contribute to a decline in the economy. Improved access to finance for households across the country is required to encourage savings. "We need to build consumer trust in financial markets so that savings can be transferred from physical to financial assets, which would create higher returns", said Renuka Sane, Associate Professor at the National Institute of Public Finance and Policy. (Sarwary, 2020) ${ }^{[7]}$.

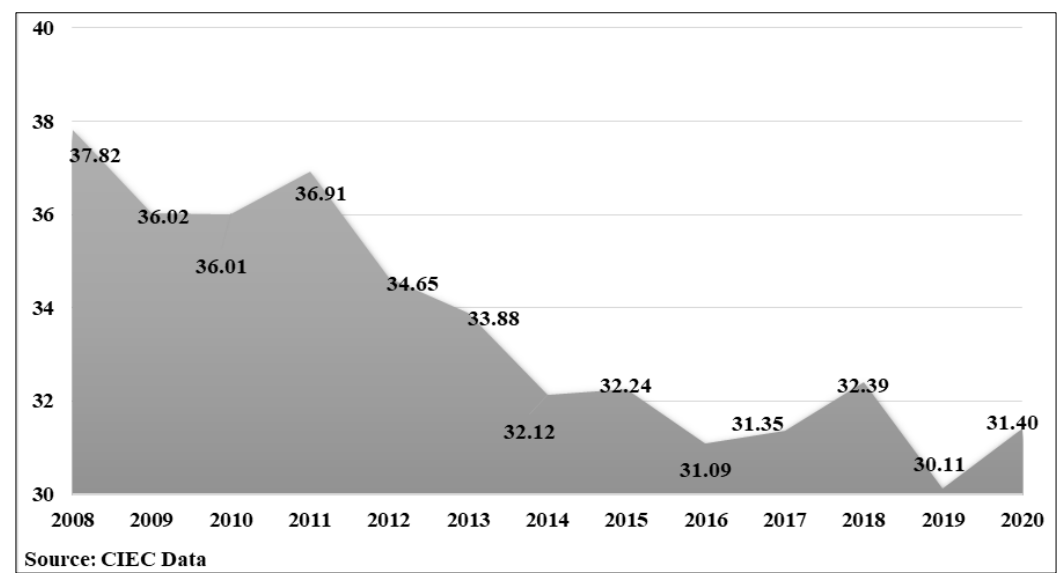

Fig 2: Gross Domestic Savings Rate (Annual) 


\section{Conclusion}

Savings are critical to the growth of the Indian economy since they finance the country's investment. It is now understood that household savings rate is not only important but it is also important to know what type of saving and investment is more helpful for growth and it is seen that Indian savings on physical assets are now focused on financial assets and that this financial asset investment can better channelize the flow of monetary policy. Despite the fact that their financial assets have experienced a secular drop. In mutual funds and insurance, there has been a recent trend in favour of financial assets. However, this is an issue that in general requires more policy attention than it has received. It is observed that the total rate of savings has increased significantly in recent years. Furthermore, it is concluded that the supply of household savings in India is sufficient to support a significantly higher rate of growth in future years if households are encouraged to invest in a variety of platforms and if households are given general support to influence their savings and investment motives. However, from the viewpoint of physical capital production, the issue is that government sectors should focus more on increasing savings.

\section{References}

1. CIEC. India Gross Savings Rate. Ciecdata, 2019, 1-35. https://www.ceicdata.com/en/indicator/india/grosssavings-rate

2. FE Bureau. Household financial savings improved in April- December 2019: RBI. Financial Express, April 2020, 1-12.

https://www.financialexpress.com/economy/householdfinancial-savings-improved-in-april-december-2019rbi/1924947/

3. Hundie SK. Savings, investment and economic growth in Ethiopia: Evidence from ARDL approach to cointegration and TYDL Granger-causality tests. Journal of Economics and International Finance 2014;6(10):232-248. https://doi.org/10.5897/jeif2014.0600

4. Jayasinghe SJANS, Liyanage MSH, Wijesundara LA, NH, Ranasinghe RDPV, Weligodapola HWMC. Investigation in to the factors influencing the savings and investment behavior on the success of small scale cinnamon planters in Sri Lanka. International Journal of Innovative Technology and Exploring Engineering 2019;8(7C2):62-68.

5. Patnaik I, Pandey R. Savings and capital formation in India, 2019. (Issue 271).

https://www.nipfp.org.in/publications/workingpapers/1866/

6. Saikia S. Investment Pattern of Youth in India with particular reference to Mumbai [S. P. Mandali's R. A. 2015. Podar College of Commerce and Economics]. https://doi.org/10.31235/osf.io/gb7as

7. Sarwary A. A study on trends and patterns of household's saving and investment on economy. International Journal of Scientific and Research Publications 2020(IJSRP);11(1):409-413.

https://doi.org/10.29322/ijsrp.11.01.2021.p10947 